\title{
FORTIFICATION AND FRONTIER: THE PROJECT DRAWN UP BY JUAN MARTÍN ZERMEÑO FOR PUEBLA DE SANABRIA IN 1766
}

\author{
V. ECHARRI \\ University of Alicante, Spain.
}

\begin{abstract}
Following the death of Engineer General Jorge Próspero de Verboom in 1744 and after a few years of transition in the management of Spanish fortifications, Juan Martín Zermeño took on the role, initially with a temporary mandate, but then definitively during a second period that ran from 1766 until his death in 1772. He began this second period with a certain amount of concern because of what had taken place during the last period of conflict. The Seven Years War (1756-1763) which had brought Spain into conflict with Portugal and England in the Caribbean had also lead to conflict episodes along the Spanish-Portuguese border.

Zermeño's efforts as a planner and general engineer gave priority to the northern part of the Spanish-Portuguese border. After studying the territory and the existing fortifications on both sides of the border, Zermeño drew up three important projects in 1766. The outposts that needed to be reinforced were located, from north to south, at Puebla de Sanabria, Zamora and Ciudad Rodrigo, which is where he is believed to have come from. This latter township already had a modern installation built immediately after the War of the Spanish Succession and reinforced with the fort of La Concepción. However, Zamora and Puebla de Sanabria had some obsolete fortifications that needed modernising.

Since the middle of the 15th century Puebla de Sanabria had had a modern castle with rounded turrets, that of the Counts of Benavente. During the 16th and 17th centuries it had also been equipped with a walled enclosure with small bastions. During the War of the Spanish Succession the Portuguese had enlarged the enclosure and had erected a tentative offshoot to the west. In order to draw up the ambitious Puebla de Sanabria project Zermeño had the aid of some previous reports and projects, such as those by the Count of Robelin in 1722, the one by Antonio de Gaver in 1752, and Pedro Moreau's report dated June 1755. This study includes a technical analysis of Zermeño's project and its strategic position within the system of fortifications along the Spanish-Portuguese border.

Keywords: fortifications, Juan Martín Zermeño, Military engineers, Puebla de Sanabria, SpanishPortuguese border.
\end{abstract}

\section{A STRATEGIC ENCLAVE}

Located on the route linking the north of Castile with the ports of Galicia and the point of departure for reaching Portugal via Braganza, since ancient times, Puebla de Sanabria had been a strategic frontier post in northwest Spain [1]. Trade between the adjacent kingdoms and the area was intensive and ongoing, and transit of people and goods was customary, further strengthened by the fact that the town also lay on the pilgrims' route to Santiago. This explains why the Catholic kings were informed in 1492 of the importance of the Spanish ports and Saelices, and why many years later Philip II made it a dry port and customs post where duties were levied on goods that had been disembarked in Vigo [2].

A few, somewhat inconclusive, intimations of the origins of Puebla de Sanabria's defences exist. According to I. Cardiñanos, 'Urbs Sanabria' is mentioned as the district's principal town in the 10th century [2]. It may well be that before that time some kind of fortification had been built by the kings of Leon as they advanced southwards during the reconquest [3]. A castle had become the seat of local government at least from the 12th century, and we know that in the 12th and 13th centuries a high medieval castle was built on the site of today's 
fortress built by the noble Pimentel family for which it provided the base. All that remains of this primitive fortress are some walls on the eastern base of the walls and the tower [3]. The fortified medieval city walls of Puebla de Sanabria also date from this period. It protected the houses in the castle vicinity. Its walls were $1.5 \mathrm{~m}$ thick with square towers and extended over 8 ha in an oval shape extending for $270 \mathrm{~m}$ from north to south and $140 \mathrm{~m}$ from east to west. There are no remains of this wall standing today. In the mid-15th century, this wall would have been practically complete, as Cardiñanos mentioned. This may be deduced from the Count of Benavente's capture of the town in 1451: 'he closed the gates of the town and closed them with their key (...) and having closed them he opened them' [4].

\section{THE CASTLE OF THE COUNTS OF BENAVENTE}

During the 15th century Puebla de Sanabria underwent a number of changes to its legal status. In 1398 Juan Alfonso Pimentel received Benavente, thanks to his part in numerous intrigues. In the civil wars that took place during the reign of Henry IV, he managed to extend his possessions to Tierra de Campos and Galicia, including la Puebla. Following disputes between Peter I and his brother Henry, the Losada family were rewarded with the gift of Sanabria for services rendered. Subsequently in 1451, during the wars between John II and Henry IV, Mayor de Porras bartered half of the town with Alonso de Pimentel, third count of Benavente. The counts of Benavente gained possession of Puebla de Sanabria in its entirety from 1479 onwards, having confiscated the assets of Diego de Losada, because he had supported the king of Portugal in the Campo Sagrado campaign. This new possession was seen by the count of Benavente as a strategic enclave for recovering the dominion of the Portuguese town of Braganza. As a result, the counts of Benavente became one of the most powerful houses in Castile.

The domain of Sanabria required a modern fortress capable of housing incipient artillery weapons. Alonso Pimentel began work on a new castle with a quadrangular base, with cylindrical towers at its corners. This is clear from his will, dating from 1455 [5]. Construction was halted at various times due to a lack of funds. In 1580 Rodrigo Alonso Pimentel recommenced work, raising the funds through a number of taxes imposed on all the inhabitants within his jurisdiction. According to Cardiñanos, the work was completed by his successors [2]. Alonso Pimentel and Ana de Velasco received Joan the Mad and Philip the Fair at the Castle in 1506. Construction was based on rammed earth walls and masonry with interlinked flagstones similar to the typical enclosures of the time. The castle has been analysed by various authors in recent years $[6,7]$. Some plans remain from later centuries which define the castle in detail, in particular that of Juan Martín Zermeño dating from 1766 (Fig. 1). As with the magnificent fortresses of that time, such as the castle of Santiago de Pamplona [8] or the castle of Salsas built by Master Ramírez [9], the castle of Sanabria soon became obsolete, unable to accommodate modern artillery weapons from the 16th century onwards.

\section{FORTIFIED WALLS IN THE 16TH AND 17TH CENTURIES}

This first medieval enclosure lent itself to fierce tax and duty controls. During the mid-16th century, as mentioned, Philip II made it the site of a dry port customs post. Cardiñanos collected a range of tolls and duties imposed on a number of products at that time. He also demanded payment from traders en route to Portugal, who by the end of the century began to use the French route, to the detriment of the area. 


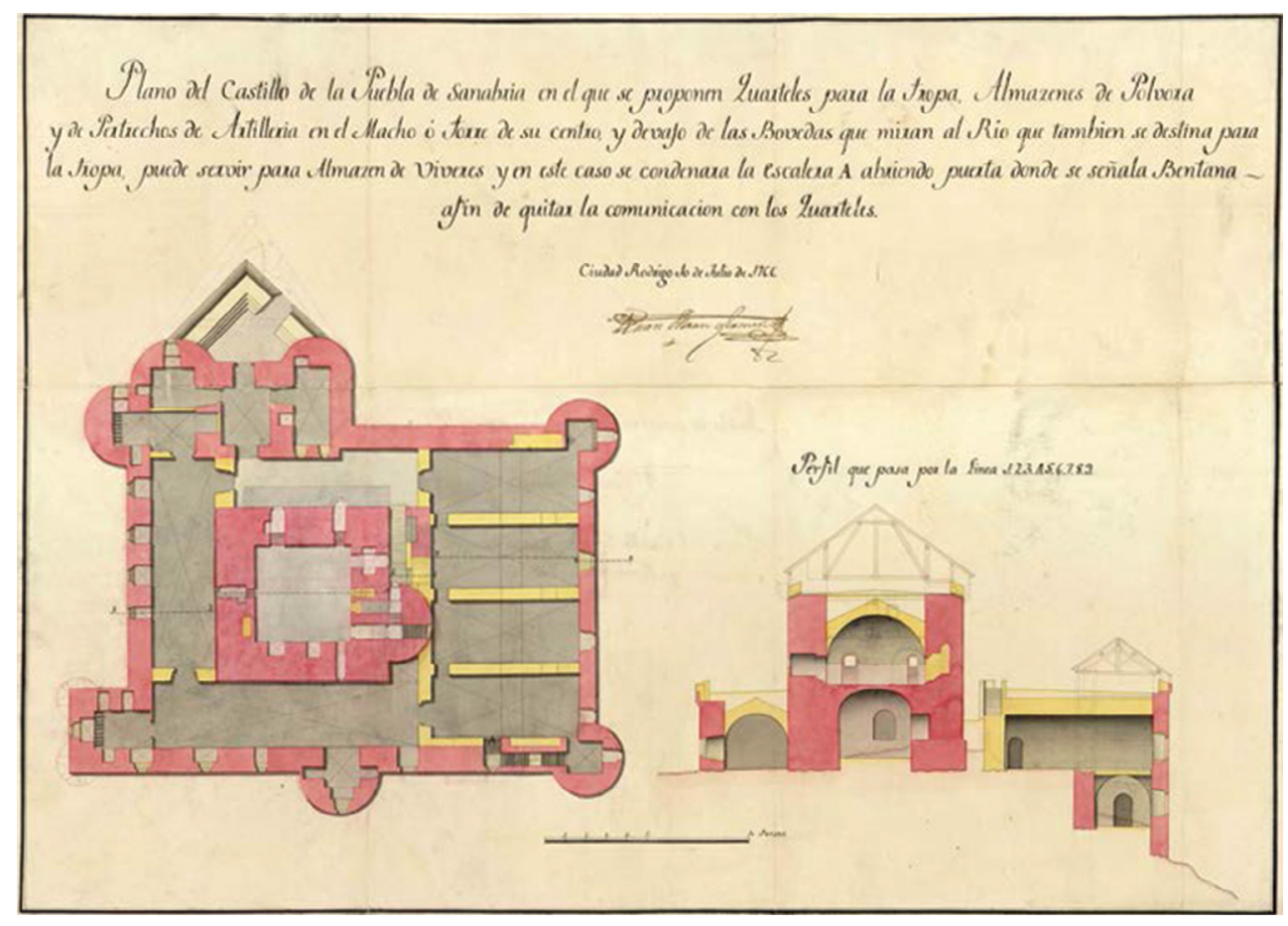

Figure 1: The castle of the Counts of Benavente. Servicio Geográfico del Ejército (SGE). Ar.E-T.7-C.2-349.

In the early years of the 16th century some of the Crown's forts, such as Cádiz, Fuenterrabía and Pamplona, underwent considerable transformations incorporating innovative designs brought from Italy. All efforts were concentrated on significant ports and on the frontier with France, while scant work was done to modernise the enclaves on the Portuguese border [10]. This neglect was confirmed with the absorption of Portugal into the Spanish monarchy in 1580. La Puebla conserved its obsolete medieval walls with its quadrangular towers, dominated by the castle. New artillery weaponry capable of launching explosive projectiles made any proper defence unviable during the early years of the 17 th century.

In 1640, after the uprising in Portugal's struggle to restore its independence, a new phase began in which work commenced to fortify Puebla de Sanabria. From 1660 to 1665, after years of acrimonious struggle, a second fortified enclosure was built complete with bastions which encompassed the whole hill with its lower slopes. This would seem to indicate that the modernisation process had begun in the 1640s, as records show that in 1642 the Spanish army advanced to Braganza with 1,500 troops and subsequently proceeded to shore up the enceinte. It was during this period that work began on the San Carlos fort in the southern part of the battlements [11]. This protective construction was one of the first modern forts built in the Spanish peninsula. Later, in the 18th century it would be criticised for its scant dimensions and because the external terrain was not easily visible. Recent excavations have recovered its foundations. 


\section{PORTUGUESE WORKS DURING THE WAR OF THE SPANISH SUCCESSION}

Existing documentation does not provide precise knowledge of how construction of the bastioned walls developed, nor is it feasible to discern this from the remains preserved today. However, using 18th century plans, a hypothesis has been put forward with respect to the possible structure of the second wall before and during the second War of the Spanish Succession. The first dates from 1715, the result of French collaboration in the war (Fig. 2). The plan is kept at the Château of Vincennes and was published by Bonet Correa [12]. It is extremely precise and describes the bastioned fortifications in place during the War of the Spanish Succession 1706.

A plan drawn up after 1722, which reflects engineer Carlos Robelin's project commissioned by Philip V, shows the works carried out by the Portuguese following the conquest of the fortress and their domination from 1710 to 1716, during the War of the Spanish Succession (Fig. 3). To the north there are two large-scale bastions in the shape of a scissor, which is quite unusual for the time. To the east a new bastion was raised looking out over the river, and, finally, a dyke in the north-western part in order to contain the waters of the river Castro. This scissor arrangement gave a strong modern aspect to the stronghold; however, it was criticised by engineers in the service of the Spanish crown, who claimed that it was inoperable. Pedro Moreau, a military engineer, drew up two further plans in 1743 and 1755, which show the two fortified walls of la Puebla and the modifications made by the Portuguese (Figs. 4 and 5).

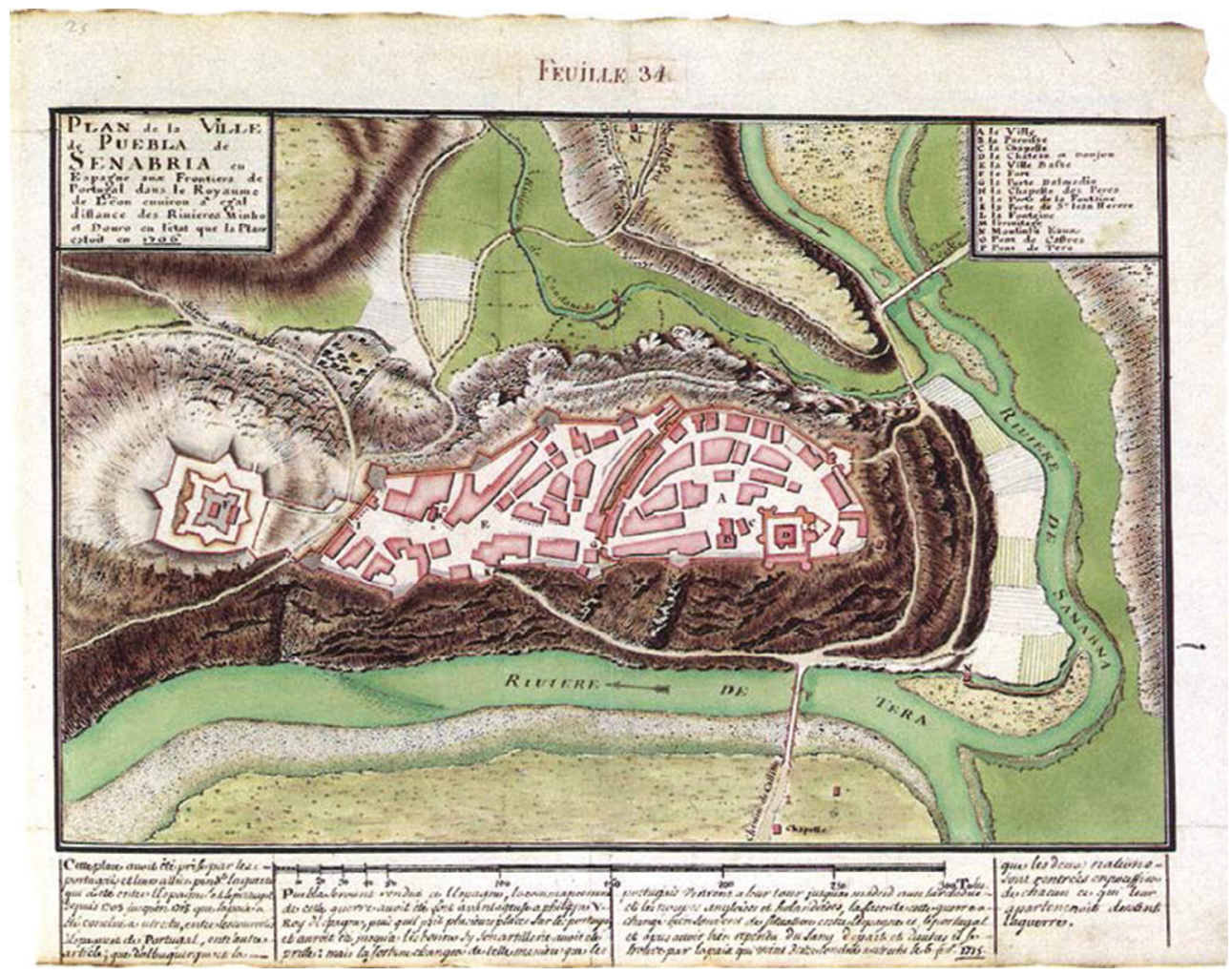

Figure 2: State of the fortifications in 1715. Service Historique de la Défense. Atlas Masse. Feuille 34. 


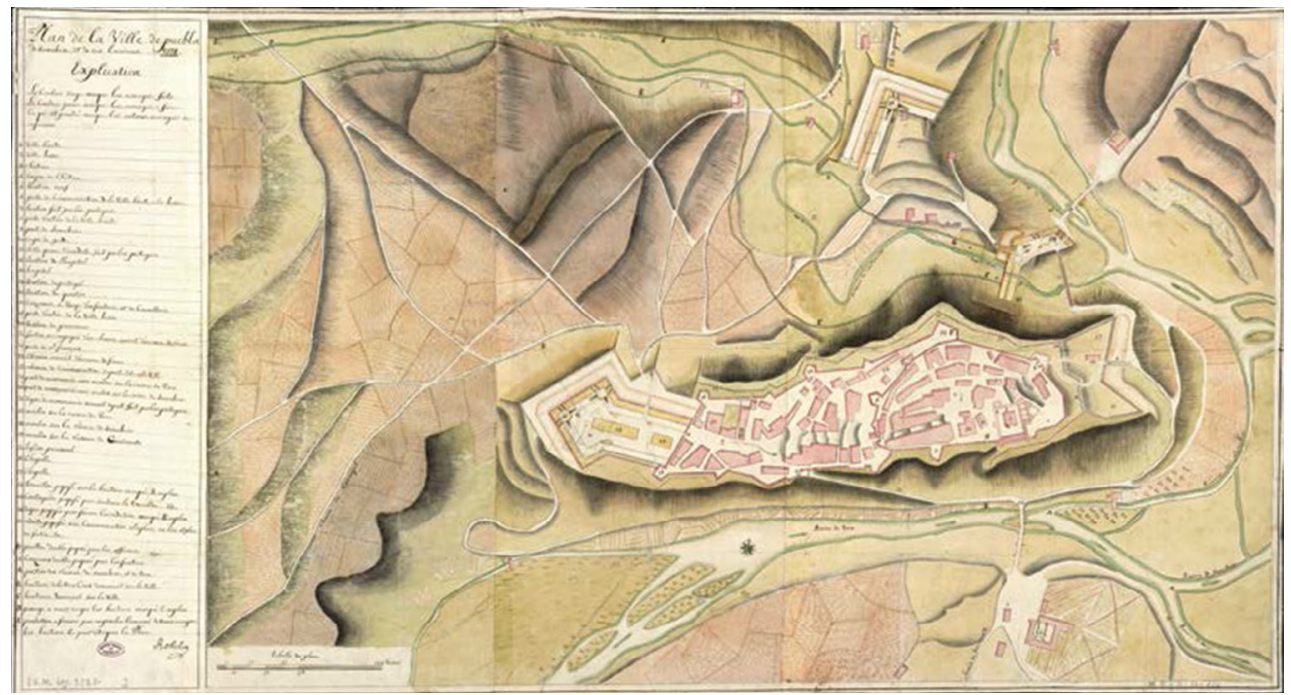

Figure 3: Carlos Robelin's project 1722. AGS. M, P yD. XI-124.

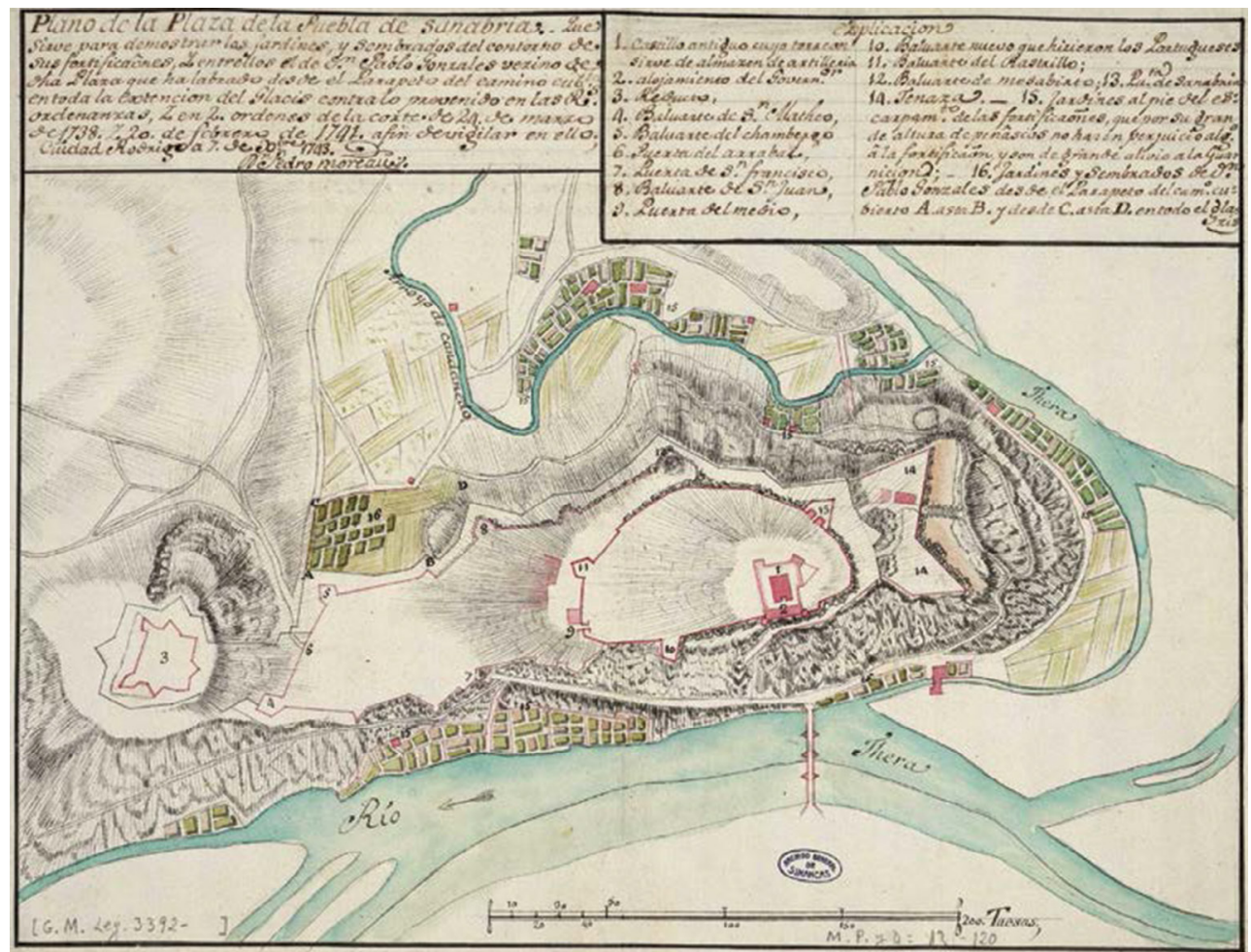

Figure 4: State of the fortifications in 1743. Pedro Moreau. AGS. M, P yD. XIII-120. 


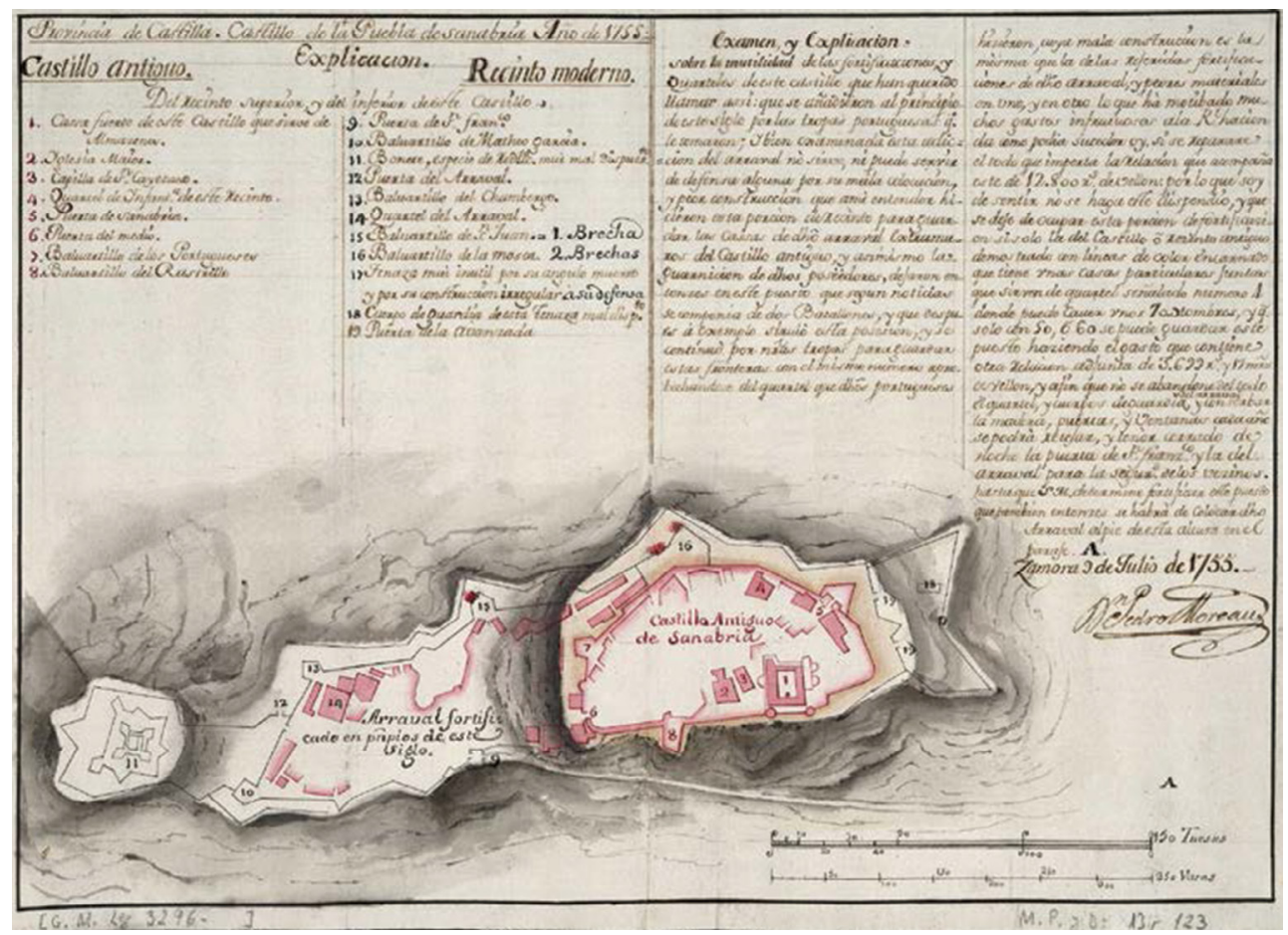

Figure 5: State of the fortifications in 1743. Pedro Moreau. AGS. M, P yD. XIII-123.

\section{JUAN MARTÍN ZERMEÑO, ENGINEER GENERAL}

After the War of the Spanish Succession, Spanish military engineers grew in scientific knowledge and technical capacity under the guidance of Engineer General Jorge Próspero de Verboom, who was originally from Antwerp [13]. His experience as a designer of fortification works and in siege warfare resulted in projects such as the Barcelona citadel and the fortifications of Alicante, Ceuta, Málaga, Pamplona, etc. Puebla de Sanabria was, together with Zamora and Ciudad Rodrigo, an important enclave on the Portuguese-Spanish border, linked to worrying episodes, such as those of the recent War of the Spanish Succession. Nevertheless, Verboom prioritised investment in the fortified strongholds on the French border.

Following Verboom's death in 1744, Francisco Manuel de Velasco, Marquis of Pozoblanco, succeeded him as Engineer General. This was a short-lived post as the second Engineer General died in 1747. Soon after, on 14 August 1749, Juan Martín Zermeño [14] was appointed temporary General Commander of the Engineering Corps assuming the duties of Engineer General until 1756 [15].

The career path of this prestigious military engineer, like that of Verboom, was exemplary and meritorious. He was a highly skilled technician with a wide knowledge of the art of fortifying, attacking and defending fortresses. He began his career as assistant engineer in 1719, because of which it is assumed that he must have been born in Ciudad Rodrigo towards the end of the 17th century. Having passed his examination for entry to the Engineering Corps, he was posted to Melilla. In 1725 he rose to the rank of Captain, and in 1726 he was promoted to Ordinary Engineer. Having taken part in the siege of Gibraltar in 1727 under Verboom, and having returned to carry out other operations in Melilla, he was again promoted 


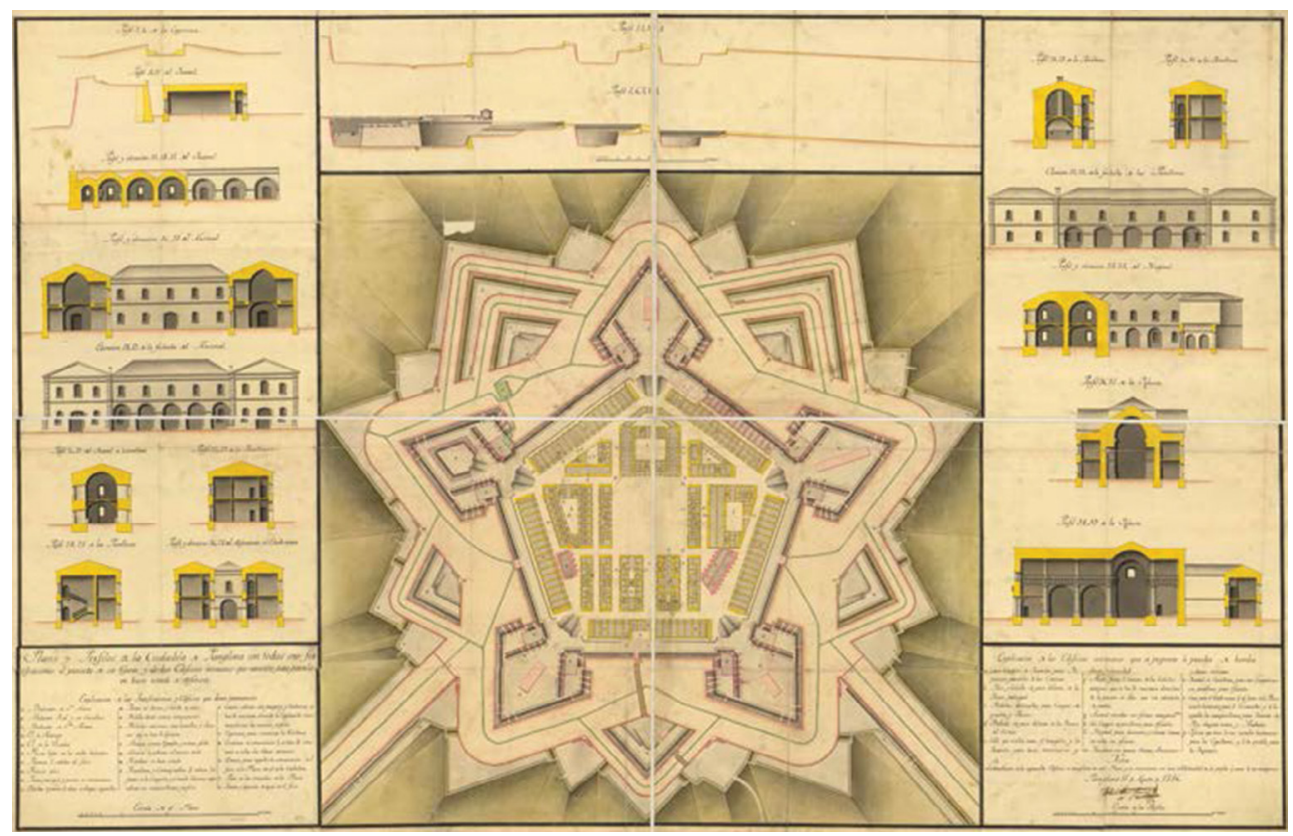

Figure 6: Plan and profiles of the Citadel of Pamplona. Juan Martín Zermeño. 7 August 1756. SGE. Ar.F-T.3-C.2-413.

on 12 September 1739 to Chief Engineer, and the following year to Infantry Colonel. He was also involved in campaigns in Italy after the 1741 treaty of alliance between Spain, France, Bavaria, Sardinia, the Two Sicilies and the Palatine Electors of Cologne and Saxony. He was wounded in one of these campaigns, during the siege of Coni. When the Chief Engineer Juan de la Ferrière was demobbed following a serious illness the Marquis of la Mina, who was commander-in-chief of the army in Italy, appointed him General Commander of Engineers as part of that army.

From the documentation in the archives of the AGS, IHCM and the SGE, in addition to other research on his scientific and professional experience, we are able to conclude that he did not possess the extensive knowledge and experience of his predecessor, the engineer from Antwerp. In this first phase, as the head of fortifications in Spain, he designed and carried out construction of the San Fernando de Figueras fort in 1753, an outstanding construction which effectively resolved defence of the French border with respect to the Principality of Catalonia [16]. Another highlight of his career was the general plan for the enceinte and port of Barcelona in 1750-1751, which involved significant work on the fortifications. He also executed an important project for the castle of Montjuich in 1751-1752. Finally, his general plan for the fortification of Pamplona merits mention, in which he corrected some of Verboom's premises [17] (Figs. 6 and 7).

After a transition stage resulting from a merger of the Engineering and Artillery Corps in 1756, and subsequent separation in 1758, Zermeño once more occupied the post of Chief Engineer following the end of the Seven Years War in a second phase from 1766 to 1773, the year of his death. When he was appointed Chief Engineer, Zermeño drew up an extensive series of projects, which included those carried out in la Puebla de Sanabria, Zamora and Ciudad Rodrigo, in addition to Cádiz, Cartagena and Orán. Having reinforced the frontier 


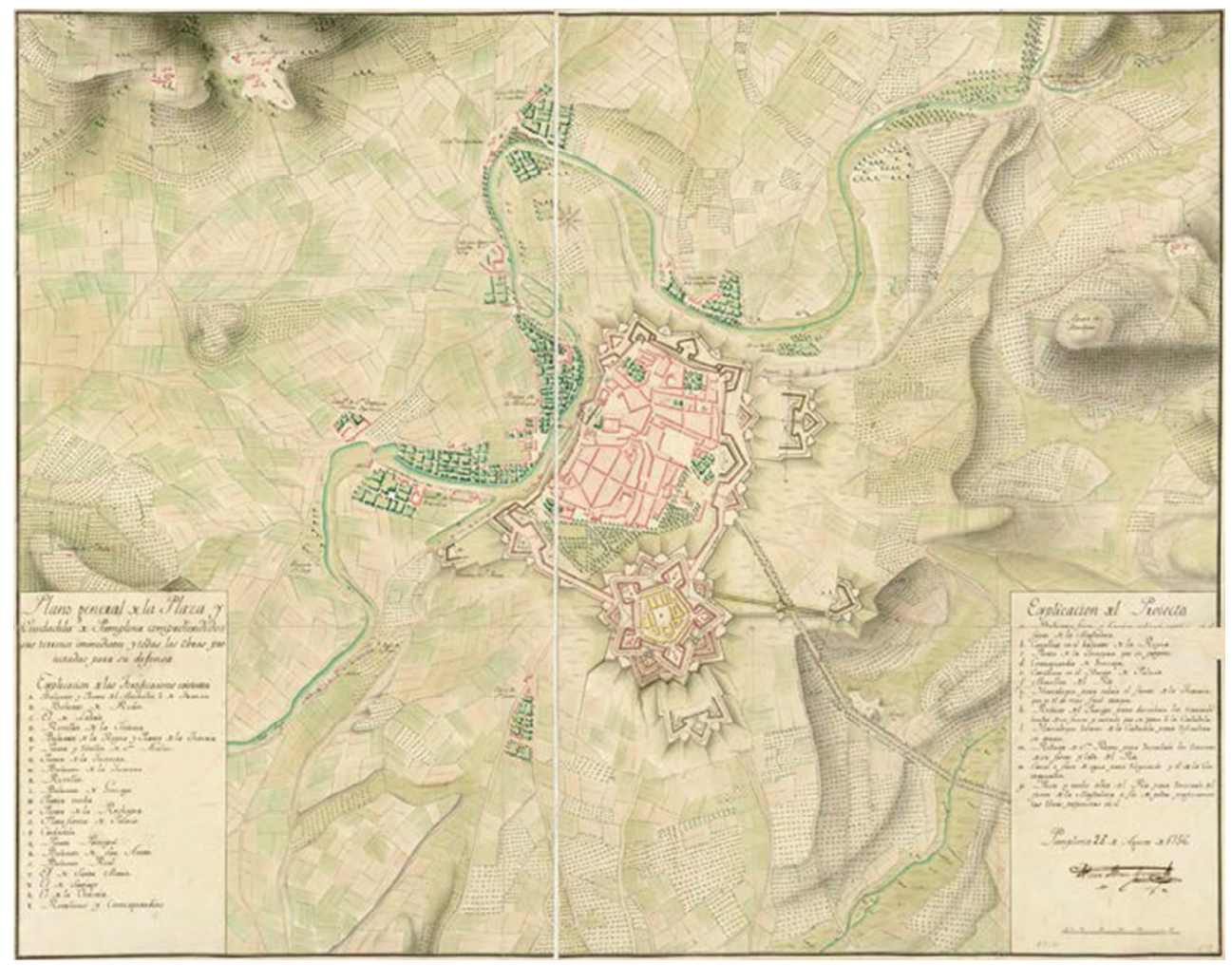

Figure 7: Zermeño's plan for the fortifications in Pamplona. 25 August 1756. SGE. Ar.FT.3-C.2-411.

fortifications on the French border, Zermeño proposed turning his attention to the most important plazas on the northern border with Portugal, which had once again suffered the consequences of a new conflict.

\section{THE SEVEN YEARS WAR: 1756-1763}

The Seven Years War (1756-1763) plunged Europe into all-out war, extending the battlefield as far as India and North America. Austria and Prussia's ambitions with regard to control of Silesia, among other causes, mainly the colonial rivalry between England and France in North America and India, led to a reversal of alliances in European politics following the Peace of Aquisgrán. Spain was subsequently to become embroiled in the war against Portugal and England in the Caribbean. It signed an alliance with France, with the third Pacte de Famille (1758-1761), which brought Spain into a war for which it was ill prepared. Military operations were launched with the invasion of Portugal by the Hispanio-French army in 1762, the capture of Havana and Manila by the British fleet and defence of the Río de la Plata after an Anglo-Portuguese invasion attempt in 1763. The Seven Years War was a conflict which altered the borders of many countries and led to a reassessment of new policies.

This belligerent context provides the backdrop to the plan devised by Zermeño for the fortifications of Puebla de Sanabria. From the start of hostilities in 1756, there was seen to be a need to speed up modernisation of the Peninsula's border fortifications. Proposals were 
put forward for improvements to most of the fortified enceintes of the strategic peninsular: Alcudia, Ayamonte, Pamplona, San Sebastián, Fuenterrabía, Cádiz, Gibraltar, Ciudad Rodrigo, Zamora, Puebla de Sanabria, La Coruña, Alicante, Cartagena, etc. Most of the projects were created in 1756 , and memorably in 1760 , and tended to decrease towards the end of the conflict.

\section{ZERMEÑO'S PROJECT FOR PUEBLA DE SANABRIA IN 1766}

Following the events of the previous war, Zermeño decided to reinforce the defences of the northern frontier with Portugal. Having examined the territory, he decided to strengthen the fortified enceintes of Puebla de Sanabria, Zamora and Ciudad Rodrigo [18], along with the Concepción fort [19]. He excluded others that in preceding centuries had been reinforced, such as Fermoselle, Torregamones, Alcañices and Carbajales de Alba [20]. The reason was simple, it was necessary to adjust investments to the most strategic sites while the fortresses provided logistic support in the form of a system of fortifications.

We have a detailed report of Zermeño's plan for Puebla de Sanabria in 1766, from which conclusions can be drawn regarding the shortcomings of the fortifications, and how they could be improved in the most rational and economic manner, adapting to the garrison provided to defend the fortified enceinte [21] (Fig. 8).

From his initial analysis of the landscape, Zermeño highlighted the dominion of the Tenaza or Lobeznos hill, situated in the east overlooking the river, whereas the western part was dominated by heights or elevations, which hampered the project. The most damaging attacks on the enceinte were unquestionably from this western end 'which is its only point of attack', 'as this elevation is the most harmful to the enceinte due to its height and layout and because there is some land for attack and battery and enemies can reach the enceinte under cover' [21, p. 6]. The northeast part was protected by a dam which the Portuguese had constructed in the gully of Candanedo, which made this a difficult part of the terrain. At the eastern line of the

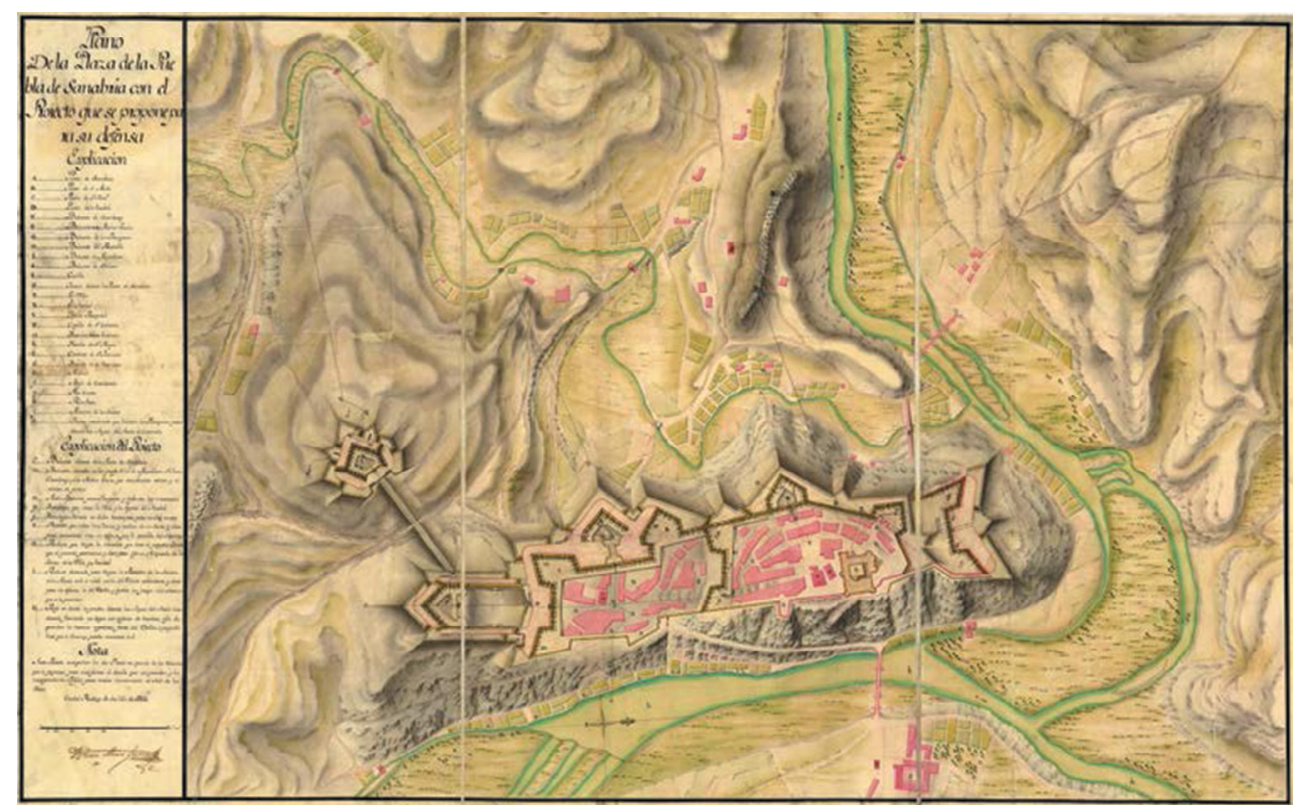

Figure 8: Zermeño’s project for Puebla de Sanabria. 10 July 1766. SGE. Ar.E-T.7-C.2-348 (1). 
walls overlooking the river Tera, the slope was considerable and the defenders had a clear advantage. Evidently, there were appropriate techniques for attack, such as undermining, but they were slow and arduous tasks which would allow the defenders time to obtain assistance.

Zermeño's report details some of the most significant effects noted in the fortified enceinte. The walls of the town at their higher part - those of the medieval period - 'were of inferior material, made from slate and clay providing little resistance for the canon' [21, p. 2]. Furthermore there were only two bastions, the Portuguese one which overlooked the river Tera, which therefore was provided with a natural defence due to the escarpment of the land, and the bastion close to the gateway, which led to the surrounding settlement. This was too small and not particularly useful. The houses in this part were too close to the parapets, making communication difficult. The tenaille built by the Portuguese in the north was deemed to be 'extremely capable', although the report criticised the moat excavated in the slate. This could be flooded by creating a dyke which would allow the flow of water from the Candanedo brook. The settlement enclosure, which was lower than that of the town, also had serious defects. It was built of slate and clay as before. It had 'four small bastions and some angles, situated very low and with the same defects as those of the town, and almost the whole part that faced west is dominated and aligned with by the adjacent hills.' 'It has an ancient badly constructed fort' was his opinion of the San Carlos fort, as it later became known. 'This fort has two enclosures, the interior being very small derelict and useless as it is so narrow; the second, although it has more capacity is also small and not very useful due to its poor construction.' Finally, the barracks were found to be small and the stores insufficient.

Zermeño's project proposed a significant transformation of the existing enclosure, making it one of the best fortified enceintes in the north of Spain. As an initial premise it was decided to build larger bastions for Puebla de Sanabria, which would be well proportioned and able to combat with their crossfire both the external surrounding land and the moat through their casemates. The dimensions of the façades and the sides - approximately $50 \mathrm{~m}$ and $20 \mathrm{~m}$ respectively - were far superior to the obsolete bastions of the previous century. However, they did not match the maximum dimensions of fortifications at that time [22], which established a flanking distance according to effective musket fire [23], some $240 \mathrm{~m}$ [24], with bastion facade lengths ranging from $75 \mathrm{~m}$ to $90 \mathrm{~m}$. This occurs with other projects designed by Zermeño, such as Pamplona, Figueras and Monjuich. The conditions of the pre-existing enceintes had a considerable effect on the potential for shaping an enclosure able to cope with the canons.

Thus it is possible to describe in order of relevance the works that Zermeño proposed in his project. The most important projects are as follows:

1. A small redoubt high on the Tenaza or Lobeznos hill (Fig. 10, right). From this elevation the western part would be covered, which would require the enemy to invest considerable time in order to capture this front and proceed to attack: 'This stronghold will defend the Fort from the aforementioned attack [that which was to replace that of San Carlos], protecting the whole western front, flanking it with their fire and covering all the intermediate gullys; therefore it would be necessary for the enemy to attack beforehand, losing time and people, allowing help to be at hand, or permitting accidents which could foil the action' [21, p. 6]. The report mentions that previously in 1752, engineer Antonio de Gaver had planned a fort at the height of Iruela. It had proved too expensive and would have been useless as it was at a distance of over 550 toises. In Gaver's plan, preserved at the SGE archives, the location of this fort was not noted (Fig. 9). It also 


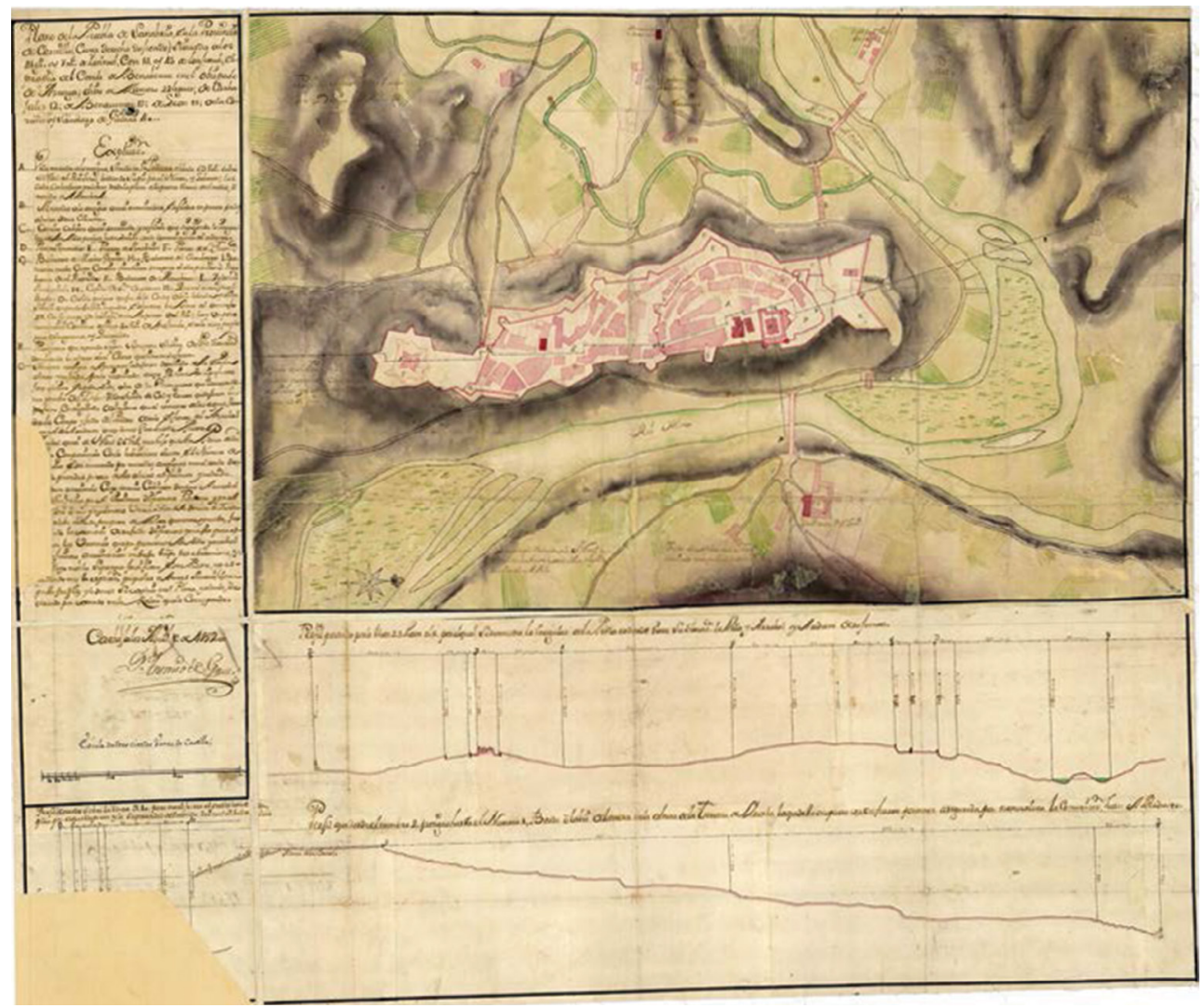

Figure 9: 'Plan of la Puebla de Sanabria'. Antonio de Gaver. April 1752. SGE. Ar.E-T.7C.2-346.

differs on this point with the opinion of engineer Carlos Robelin, who in 1722 had proposed dominating the Vera Cruz elevation with a tenaille at a distance of some 200 toises from the enceinte (Fig. 3).

2. A new fort replacing the existing one at the southern elevation of the settlement. It would be a notable stronghold or bastion which connected with the enciente (Fig. 10, left). It would have a weak gorge and a safeguard for the troops which could be destroyed if the enemy were to capture it. It would contain accommodation for the troops.

3. Reformation of the layout of the tenaille built by the Portuguese half a century earlier to the north of the plaza. It was a serious defect which could be remedied at a low cost. A tenaille was to be built in front of the Sanabria gate, shortening its facades forming flanks and wall curtains, thus removing the dead angle. This would result in a staggered defence towards the river. It also suggested re-establishing the dam built by the Portuguese to contain the waters of the Candanedo brook which was in ruins, creating a new one with palisade and stone in front of the Moscabirote bastion. The land in this part would be waterlogged, facilitating defence and preventing the enemy from capturing the heights of the Tenaza. Similar techniques had been employed for centuries in Holland (Fig. 11). 


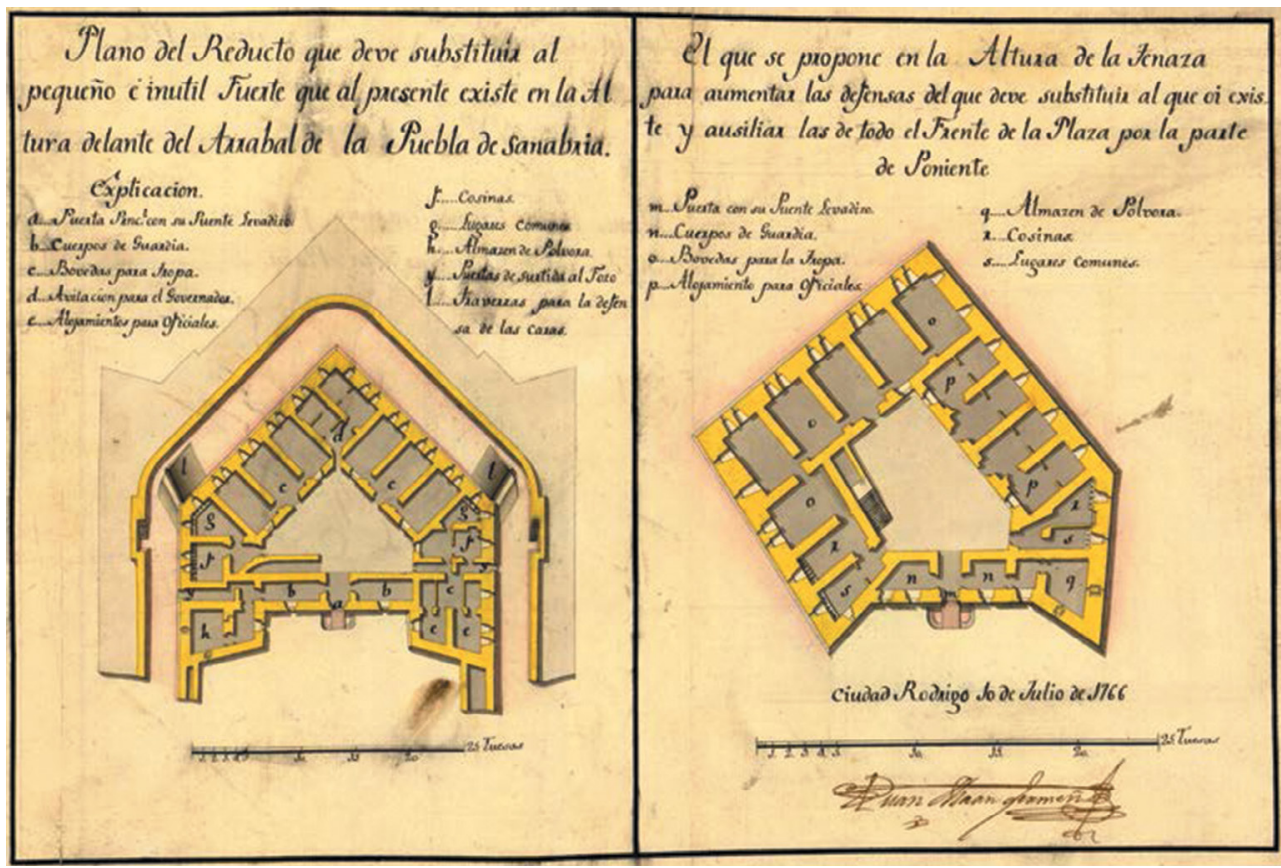

Figure 10: Redoubts planned by Zermeño. 10 July 1766. SGE. Ar.E-T.7-C.2-350.

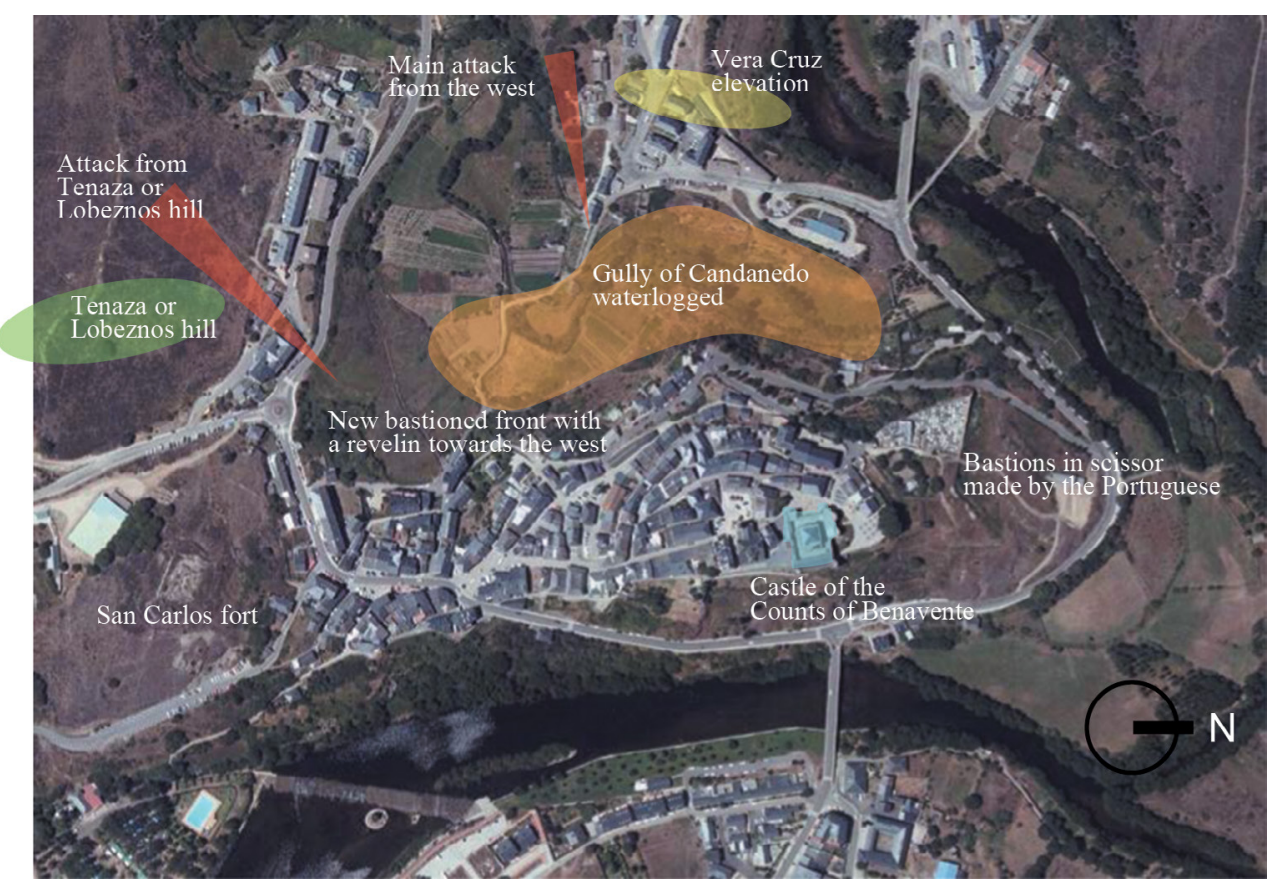

Figure 11: Description of elements and possible attacks on the current state of the town. 
The remaining proposals addressed how to modernise the existing bastions or add new ones. Two enclosures would remain at two different levels well contained on their fronts and curtain walls:

4. Construction of a new bastion in the Sanabria gateway. It was extremely important due to its situation.

5. Incorporation of the Moscabirote bastion in the upper enceinte, which had been part of the settlement enclosure, increasing and improving it.

6. A front with two half bastions in front of the gateway known as midway, which overlooked the settlement. Its curtain walls connected with the lower curtain walls of the settlement.

7. Arrangement of three new and extensive bastions in the lower enclosure of the settlement, 'rebuilding all its walls and creating another half bastion in the part of the river Tera, in order to flank and defend the whole front with the aid of the Portuguese bastion' [21, p. 5]. They would be known as the San Juan, Chambergo and Mateo García bastions. The last two were laid out on two existing bastions of the same name, but were built in such a way that they corrected the obliqueness with regard to the front in respect of the San Carlos fort, 'so that their fire would be direct, the front regular and their capacity sufficient as the present bastions are extremely reduced'.

8. Reinforcement of the western front of the settlement. A revelin between the San Juan and Chambergo bastions was proposed which was to be well proportioned and would communicate through its gorge with the curtain wall. Nothing was mentioned of this communication project. With regard to the plan, it was similar to the layout of caponiers for defending the moat, which was typical of the era, and which Zermeño would introduce in other fortifications such as Zamora or Ciudad Rodrigo [25], following the proposals of the Marquis of Montalembert [26]. It was essential to reinforce this western front which, due its nature, was at a lower level of the front of the Moscabirote and Sanabria bastions, and the planned fort in Lobeznos.

With respect to the town enceinte, it was urgent to rebuild the masonry walls from the gateway of Sanabria up to its closure, maintaining the Portuguese bastion, which although apparently useless was well constructed. Regarding the treatise on the need to provide good barracks - since there were only two, one in town and another in the settlement - for 500 infantry and 80 horses, it was proposed that the castle of the counts of Benavente should be reformed and renovated so that it could fulfil this function. Its construction was solid and would provide every guarantee of protection in the event of a siege, such as the provisions store (Fig. 1).

As may be seen, the project was an ambitious one and substantially altered the pre-existing fortifications. Zermeño would not quantify the costs of the intervention as he had done for other projects. Aware of the difficulties the Royal Treasury faced in providing resources, he explained that in his view they were important advantages and they justified the choice of Puebla de Sanabria as the main fortification of the northern Spanish-Portuguese border:

Firstly because most of these would not require excavation for their foundations as the rock is open or very close thus providing their base. Secondly, because the materials are nearby and extremely suitable and thirdly because the workers on the land are moderate [21, p. 7].

The greatest inconvenience was the lack of lime for making mortar. Previously, this had been easily available from the Campos or from Portugal at a reasonable price; however, as it was 
no longer possible, it would be necessary to bring two master masons from Catalonia who could make lime using pebbles, as they had been doing in Figueras and Barcelona. The river Tera was full of raw materials, and timber was guaranteed in the surrounding area.

Zermeño completed his explanation ratifying the importance of Puebla de Sanabria in defending the Spanish border, making it more important than the Zamora fortifications due to its strategic importance:

[A]nd it only remains to add that if your Majesty decides to improve the fortifications on this border such action should be preferred to reinforcing Zamora, given its proximity to the neighbouring kingdom, the facility of its entries and communications, the country that covers and safeguards its location on the river Tera, and the aid that can be supplied to the Territories of Alcañices to the banks of the Esla, from all of which it may be deduced that this provides convincing evidence of this Opinion.

The Zermeño project was never executed for reasons of economy; however, it was a rational exercise involving enormous technical mastery designed to ensure sufficient defence of the border passage with a minimal investment of resources.

\section{CONCLUSIONS}

Puebla de Sanabria was from the earliest times a strategic enclave of the first order in defending the Spanish-Portuguese border. This was reinforced in the 17th and 18th centuries due to Portugal's war of independence, the War of the Spanish Succession and the Seven Years War, in which the town played an important role with significant episodes.

The fortifications of this Zamoran town underwent a development similar to those of numerous Spanish border fortifications. To an initial medieval enceinte, overlooked by its imposing 15th century castle, was added a second bastion construction and a small external fort, thus circling the entire hill with fortifications at various levels. The walls were of poor quality - slate and clay - due to the scarcity of lime and the lack of financial resources. The bulwarked enclosure had few bastions and these were small with scant artillery capacity. Puebla de Sanabria was considered of less importance than other fortifications such as Ciudad Rodrigo or Zamora.

After the Seven Years War, and taking into account modernisation of the strongholds along the French border and in the coastal enclaves carried out in the first half of the 17th century, engineer general Juan Martín Zermeño, in his second period at the head of the Military Engineering Corps, carried out three significant projects on the Spanish-Portuguese border. He raised the matter of Puebla de Sanabria's strategic importance, and prioritised this over the Zamora enceinte. He was critical of the state of the fortifications, mainly the poor layout of the San Carlos fort, and the detrimental nature of the tenaille built by the Portuguese during the War of the Spanish Succession, which also introduced dead angles. He must certainly have analysed earlier projects such as those of engineer Carlos Robelin, from whom he took the idea of replacing the San Carlos fort with a prominent bastion. However, he distanced himself from reinforcing the height of the Vera Cruz with a tenaille and a counter-guard between this tenaille and the city. He also criticised Antonio de Gaver's recent proposal to build a fort on the Iruela hill, which he considered too far from the fortifications.

The Zermeño project was coherent and provided a masterly solution and in a manner aligned with available resources in terms of the work required. He had to address the difficult task of modernising two obsolete enceintes with extremely small bastions adapting to the 
form and outline of the existing hill and its immediate elevations. Due to all these conditioning factors, it was necessary to reduce the flanking distance and the length of the bastion facades by $40 \%$ in contrast to the maximum fortification measurements of the time. The most important aspects of this project focused on construction of a stronghold at the height of Lobeznos, communicating with a prominent bastion which would replace the San Carlos fort; a new northern front rebuilding the tenaille and creating flanks on the bastions and the curtain walls between them; and a renovated front to the west with the bastions of San Juan and Chambergo, in addition to a revelin in front of these.

\section{REFERENCES}

[1] Guitart Aparicio, Cristóbal, Consideraciones sobre plazas fuertes y castillos españoles ante la frontera de Portugal. Castillos de España, 100, 1993, pp. 35-42.

[2] Cardiñanos Bardeci, I., La Puebla de Sanabria y sus Fortificaciones. Anuario del Instituto de Estudios Zamoranos Florián Ocampo, Zamora, pp. 389-404, 1991.

[3] Lobato Vidal, José Carlos, Castillos y Murallas de la Provincia de Zamora, Editoral Semuret: Zamora, 1997.

[4] Archivo Histórico Nacional (AHN). Osuna. Carp. 61.

[5] Archivo Histórico Nacional (AHN). Osuna. Cons. Leg. 37.741.

[6] Gutiérrez González, José Avelino, Arquitectura militar y sistemas de fortificaciones en el reino de León. Castillos medievales del reino de León, ed Miguel Angel Ladero Quesada, Hullera Vasco-Leonesa: Madrid, pp. 157-174, 1989.

[7] Estal López, Ma Teresa del, El Castillo de Puebla de Sanabria, Ayuntamiento de Puebla de Sanabria: Puebla de Sanabria, 2008.

[8] Echarri Iribarren, Víctor, Las Murallas y la Ciudadela de Pamplona, Departamento de Educación y Cultura-Institución Príncipe de Viana, Gobierno de Navarra: Pamplona, 2000.

[9] Bayrou, L., Faucherre, N., Quatrefages, R., La Fortaleza de Salses: Pirineos Orientales, Monum, éditions du patrimoine: París, 2003.

[10] Porras Gil, C., La organización defensiva española en los siglos XVI-XVII. Desde el río Eo hasta el Valle de Arán, Universidad de Valladolid: Valladolid, 1995.

[11] Marcos Contreras, Gregorio José, El Fuerte de San Carlos en Puebla de Sanabria. Fortificaciones Abaluartadas de la Provincia de Zamora, ed Hortensia Larrén Izquierdo, Junta de Castilla y León: Zamora, pp. 43-60, 2010.

[12] Bonet Correa, Antonio, Cartografía Militar de Plazas Fuertes y Ciudades Españolas. Siglos XVII-XIX, Ed. Artegraf: Madrid, 1991.

[13] Muñoz Corbalán, J.M., Verboom: Jorge Próspero Verboom: ingeniero militar flamenco de la monarquía hispánica, Fundación Juanelo Turriano: Madrid, 2015.

[14] De La Llave Y García, Joaquín, D. Juan Martín Zermeño, Teniente General e Ingeniero General. Revista del Memorial de Ingenieros, vol. XXVIII, 5a, Madrid, pp. 161-164, 1911.

[15] Capel, Horacio, Los ingenieros militares y el sistema de fortificación en el siglo XVIII. Los ingenieros militares de la monarquía hispánica en los siglos XVI y XVII, Alicia Cámara Muñoz (coord.), Ministerio de Defensa: Madrid, pp. 231-267, 2005.

[16] De La Fuente, Pablo, El proyecto de la fortaleza de San Fernando de Figueras. Una aportación al conocimiento de la dirección interina de Juan Martín Cermeño al frente de los ingenieros reales, Espacio, Tiempo y Forma, Serie VII, $H^{a}$ del Arte, 7, pp. 201-211, 1994. 
[17] Echarri Iribarren, Víctor, El proyecto de Juan Martín Zermeño para las fortificaciones de Pamplona: una revisión del Proyecto General de Verboom. Tiempos Modernos. Revista Electrónica de Historia Moderna, 8(30), junio 2015.

[18] Cobos Guerra, F. \& Campos, J., Almeida/Ciudad Rodrigo. La Fortificación de la Raya Central, Consorcio Transfronterizo de Ciudades Amuralladas: Salamanca, 2013.

[19] Rodríguez De La Flor, F., La Frontera de Castilla. El Fuerte de la Concepción, Diputación de Salamanca: Salamanca, 2003.

[20] Cruz Sánchez, Pedro J., El Fuerte de Carbajales de Alba. Fortificaciones Abaluartadas de la Provincia de Zamora, ed Hortensia Larrén Izquierdo, Junta de Castilla y León: Zamora, pp. 29-41, 2010.

[21] Relacion de la plaza de la Puebla de Sanabria y proiecto para su defensa. Juan Martín Zermeño. 10 de julio de 1766. Servicio Geográfico del Ejército. M.I.D. C-58 no 34.

[22] Vauban, Sébastien Le Prestre, Veritable Manière de Fortifier de Mr. de Vauban. Où l'on voit de quelle méthode on se sert aujourd'hui en France..., Amsterdam, Chez Pierre Mortier: Paris, 1689.

[23] Warmoes, Isabelle, Vauban et l'art de la fortification. Vauban, bâtisseur du Roi-Soleil, ed Isabelle Warmoes, Catálogo de la exposición organizada por la Cité de l'architecture et du patrimoine, Paris, del 14 de noviembre de 2007 al 5 de febrero de 2008, Somogy éditions d'art: París, pp. 190-197, 2007.

[24] Chafrion, Ioseph, Escuela de Palas o sea Curso Mathematico dividido en XI tratados, que contienen la Arithmetica, Geometria Speculativa... y ultimamente el Arte Militar, Emprenta Real, por Marcos Antonio Pandulpho Malatesta: Milan, 1693.

[25] Cobos Guerra, F. \& Castro Fernández, F.J. de, Castillos y Fortalezas de Castilla y León, Edilesa: León, 1998.

[26] Montalembert, Marquis de, La Fortification Perpendiculaire, ou Essai sur plusieurs manieres de fortifier..., Imprimerie de Philippe-Denys Pierres: París, 1776. 